\title{
REACTION BETWEEN DEHYDROASCORBIC ACID AND DIALYSED LENS EXTRACT IN VITRO*
}

\author{
BY
}

\section{J. GLOSTER}

From the Institute of Ophthalmology, University of London Director of Research: Sir Stewart Duke-Elder

IT is generally accepted that the high concentration of ascorbic acid in the aqueous humour in some species is due to active transfer of this substance from the plasma into the eye by the ciliary epithelium. However, the possibility of ascorbic acid formation in the eye has not been disproved, and Bárány and Langham (1955) stated that, in the rabbit, a concentration of $10-14 \mathrm{mg} . / \mathrm{ml}$. ascorbic acid in the aqueous humour could be due to synthesis within the eye.

Some recent experiments in vitro (Mishima, 1952; Uyama and Ogino, 1955; Uyama, Ogino, and Mishima, 1955) suggest that ascorbic acid may be formed in the lens from mannose or glucose, but earlier investigations were concerned with the possibility of the formation of ascorbic acid from dehydroascorbic acid. Borsook, Davenport, Jeffreys, and Warner (1937) found that dehydroascorbic acid was reduced rapidly at $p \mathrm{H} 7$ and $37 \cdot 5^{\circ} \mathrm{C}$. by glutathione, and the possibility that this reaction occurs in the lens resulting in ascorbic acid formation, was studied by Kinsey (1950). He found that when solutions of dehydroascorbic acid were incubated with intact cattle lenses there was no ascorbic acid formation, but reduction of dehydroascorbic acid was observed when crushed lenses were used. Despite these in vitro results, Kinsey found that the injection of dehydroascorbic acid solutions into the posterior chamber of the living rabbit did not give rise to an increased concentration of ascorbic acid in the anterior chamber.

Recently, Langham and Heald (1956) have studied the effect of dialysed extracts of rabbit lenses upon the reaction between dehydroascorbic acid and reduced glutathione. They found that the addition of dialysed lens extract increased the rate of formation of ascorbic acid, but considered that the acceleration of the reaction was probably not enzymic. This view was supported by two observations:

(i) The acceleration of the reaction was not abolished by heating the lens extract (but was, in fact, increased);

(ii) Some ascorbic acid was formed when lens extracts were incubated with dehydroascorbic acid in the absence of glutathione.

The present investigation was undertaken to follow up these observations by studying the reaction between dialysed lens extracts and dehydroascorbic acid. It was of particular interest to ascertain whether this reaction was influenced by previous heating of the lens extract. Also, some features

* Received for publication May 18, 1956. 
of the reaction between dehydroascorbic acid and lens extract were compared with the reaction between dehydroascorbic acid and reduced glutathione.

\section{Methods}

(1) Preparation of Lens Extracts.-Lenses were removed from the eyes of adult pigmented rabbits not more than $30 \mathrm{~min}$. after the death of the animal. The lenses were ground up with glass powder and twice their volume of glass-distilled water. The resulting mush was transferred to $\frac{1}{2}$-inch diameter dialysis tubing, and was dialysed against running tap-water for 4-8 hrs at room temperature and afterwards against glass-distilled water for $16-20 \mathrm{hrs}$ in a refrigerator at $4^{\circ} \mathrm{C}$. During this period the glass-distilled water was changed two or three times. The total duration of dialysis was not less than $24 \mathrm{hrs}$. After dialysis, the extract was centrifuged at 3,000 r.p.m. for $20 \mathrm{~min}$. and the supernatant liquid was used for the experiments.

(2) Preparation of Solutions of Dehydroascorbic Acid (DHA).-60 mg. ascorbic acid was dissolved in $10 \mathrm{ml}$. glass-distilled water. Bromine was added slowly until the faintest yellow colour appeared. Nitrogen was bubbled through the solution and this was continued for $20 \mathrm{~min}$. after the disappearance of the yellow colour. The $p \mathrm{H}$ of the solution was adjusted to 7 by the addition of sodium hydroxide solution.

In some experiments, the DHA solution was prepared from dehydroascorbic acid methanolate $(6 \mathrm{mg} . / \mathrm{ml}$.).

(3) Reaction between Dehydroascorbic Acid Solution and Dialysed Lens Extract. -The experiments were conducted at $p \mathrm{H} 7$ in a Sorensen phosphate buffer. The DHA solution, lens extract, and buffer were incubated in stoppered glass tubes in a water-bath at $37^{\circ} \mathrm{C}$. Three tubes were usually set up as follows:

\begin{tabular}{c|c|c|c|c}
\hline Tube & $\begin{array}{c}\text { Sorensen Buffer } \\
p \mathbf{H} 7 \cdot 0,0.06(\mathrm{ml} .)\end{array}$ & Water (ml.) & $\begin{array}{c}\text { Lens } \\
\text { Extract (ml.) }\end{array}$ & $\begin{array}{c}\text { DHA } \\
\text { Solution (ml.) }\end{array}$ \\
\hline II & 0.8 & $3 \cdot 2$ & 1.4 & 0 \\
III & 0.8 & $4 \cdot 1$ & 0.5 \\
\hline
\end{tabular}

In two experiments $1.6 \mathrm{ml}$. buffer were used, with a corresponding reduction in the volume of water added, in order to retain a total volume of $5.4 \mathrm{ml}$.

Immediately after addition of the lens extract and DHA, the contents of a tube were mixed rapidly and $0.2 \mathrm{ml}$. was withdrawn for titration against 2:6-dichlorophenolindophenol. The tube was then placed in the water-bath at $37^{\circ} \mathrm{C}$. At 20,40 , and $60 \mathrm{~min}$. after the beginning of incubation, further specimens of $0.2 \mathrm{ml}$. were withdrawn from the tubes and titrated against 2:6-dichlorophenolindophenol.

(4) Reaction between Dehydroascorbic Acid Solution and Reduced Glutathione $(G S H) .-1 \mathrm{ml}$. glutathione solution was incubated with $0.8 \mathrm{ml}$. Sorensen buffer $(p \mathrm{H} \mathrm{7}), 3.1 \mathrm{ml}$. water, and $0.5 \mathrm{ml}$. DHA solution, following a procedure similar to that described for the reaction between DHA and lens extract. The GSH solution was prepared immediately before the start of the experiment by dissolving 
$20 \mathrm{mg}$. reduced glutathione (Distillers' Company) in $10 \mathrm{ml}$. water. Titration with iodine showed that the glutathione was 95 per cent. pure with respect to sulphydryl groups.

(5) Titration with 2:6-dichlorophenolindophenol.-A stock solution of 2:6dichlorophenolindophenol was prepared by dissolving $100 \mathrm{mg}$. dye in $100 \mathrm{ml}$. distilled water. Before each experiment, one part of the stock solution was diluted with two parts of distilled water and filtered. The titration was done in a phosphate-citrate buffer $p \mathrm{H} \mathrm{4}$, prepared by mixing three vols $0.2 \mathrm{M}$ disodium hydrogen phosphate with five vols $0 \cdot 1 \mathrm{M}$ citric acid.

$0.14 \mathrm{ml}$. diluted dye solution were added from a micro-burette to $4 \mathrm{ml}$. phosphatecitrate buffer in a colorimeter tube. Each $0 \cdot 2-\mathrm{ml}$. sample, withdrawn from a tube during incubation, was added to the contents of the colorimeter tube, and readings of the optical density were taken in an "EEL" portable colorimeter at 60,90 , and $120 \mathrm{sec}$. after mixing. Repeated readings of the optical density were taken in this way in order to minimize interference from substances which decolorize 2:6dichlorophenolindophenol at a slower rate than ascorbic acid. If fading did occur during the titration, a correction was applied by adding the difference between the 60 and $120 \mathrm{sec}$. reading to the $60 \mathrm{sec}$. reading, so that a value was obtained for the optical density at the time of adding the sample of reaction mixture to the dye. The $90 \mathrm{sec}$. reading was of value in determining whether the rate of fading was uniform over this period; this was found to be so in the majority of titrations.

After each experiment, the dye solution was titrated against three standardo solutions of ascorbic acid containing 30,20 , and $10 \mathrm{mg} . / 100 \mathrm{ml}$. respectively $0.1 \mathrm{ml}$. of each standard solution was added in turn to $4 \mathrm{ml}$. phosphate-citrateo buffer containing $0.14 \mathrm{ml}$. dye solution, and colorimeter readings were taken. A? blank determination, omitting the ascorbic acid, was also done. With these data, the titration values of the specimens withdrawn from the reaction mixtures could be expressed in terms of ascorbic acid concentration. Whether or not it is justifiable to assume that their capacity to decolorize the dye is due entirely to their ascorbic acid content will be discussed later, and, bearing this in mind, the results will be expressed as concentrations of AA in $\mu \mathrm{g} . / \mathrm{ml}$.

\section{Results}

(a) Reaction between Lens Extract and Dehydroascorbic Acid.-Fig. 1 (opposite) shows an experiment in which lens extract was incubated with DHA, in the presence of a Sorensen buffer $p \mathrm{H} \mathrm{7}$; it shows that the concentration of AA increased more rapidly in the tube containing buffer, DHA, and lens extract than in the other two tubes, one of which contained buffer and DHA, and the other buffer and lens extract. Similar results were obtained in eight experiments, the results of which are given in Table I (opposite).

In experiments with extracts $\mathrm{L} 7$ and $\mathrm{L} 8,1.6 \mathrm{ml}$. buffer was used instead of the usual $0.8 \mathrm{ml}$. In each experiment the concentration of AA in Tube III exceeded the sum of the concentrations of AA in Tubes I and II at the corresponding times. 
FIG. 1.-Reaction between DHA and dialysed lens extract.

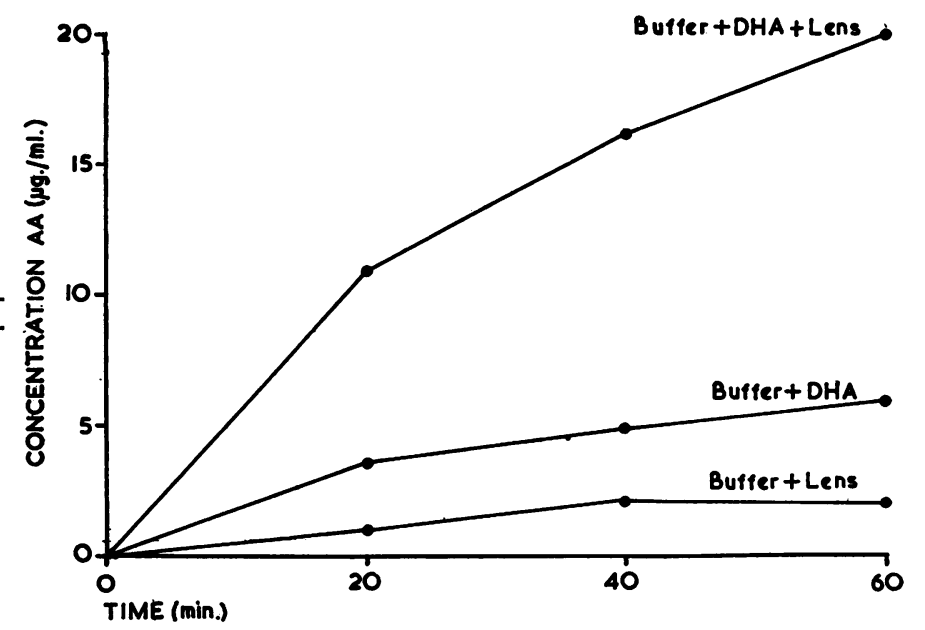

TABLE I

REACTION BETWEEN LENS EXTRACT AND DHA

\begin{tabular}{|c|c|c|c|c|}
\hline \multirow[b]{2}{*}{$\begin{array}{c}\text { Lens } \\
\text { Extract }\end{array}$} & \multirow[b]{2}{*}{$\begin{array}{c}\text { Time } \\
\text { (min.) }\end{array}$} & \multicolumn{3}{|c|}{ Concentration of AA $(\mu \mathrm{g} / \mathrm{ml})}$. \\
\hline & & $\begin{array}{l}\text { Tube I } \\
\left\{\begin{array}{l}\text { Buffer } \\
\text { Lens Extract }\end{array}\right.\end{array}$ & $\begin{array}{l}\text { Tube II } \\
\left\{\begin{array}{l}\text { Buffer } \\
\text { DHA }\end{array}\right.\end{array}$ & $\begin{array}{l}\text { Tube III } \\
\left\{\begin{array}{l}\text { Buffer } \\
\text { Lens Extract } \\
\text { DHA }\end{array}\right.\end{array}$ \\
\hline L.1 & $\begin{array}{l}20 \\
40 \\
60\end{array}$ & $\begin{array}{l}2 \cdot 6 \\
6 \cdot 0 \\
3 \cdot 4\end{array}$ & $\begin{array}{l}0 \\
0 \\
0\end{array}$ & $\begin{array}{l}12 \cdot 9 \\
17 \cdot 2 \\
19 \cdot 8\end{array}$ \\
\hline L.2 & $\begin{array}{l}20 \\
40 \\
60\end{array}$ & $\begin{array}{l}0 \\
0 \cdot 6 \\
2 \cdot 3\end{array}$ & $\begin{array}{l}2 \cdot 8 \\
2 \cdot 3 \\
5 \cdot 1\end{array}$ & $\begin{array}{r}8 \cdot 4 \\
14 \cdot 0 \\
16 \cdot 3\end{array}$ \\
\hline L.3 & $\begin{array}{l}20 \\
40 \\
60\end{array}$ & $\begin{array}{l}2 \cdot 9 \\
2 \cdot 9 \\
3 \cdot 5\end{array}$ & $\begin{array}{l}1 \cdot 2 \\
1 \cdot 2 \\
2 \cdot 3\end{array}$ & $\begin{array}{r}9 \cdot 3 \\
13 \cdot 4 \\
13 \cdot 9\end{array}$ \\
\hline L.4 & $\begin{array}{l}20 \\
40 \\
60\end{array}$ & $\begin{array}{l}0.7 \\
2 \cdot 0 \\
2 \cdot 0\end{array}$ & $\begin{array}{l}3 \cdot 4 \\
4 \cdot 7 \\
6 \cdot 0\end{array}$ & $\begin{array}{l}10 \cdot 7 \\
16 \cdot 0 \\
20 \cdot 1\end{array}$ \\
\hline L.5 & $\begin{array}{l}20 \\
40 \\
60\end{array}$ & $\begin{array}{l}6 \cdot 1 \\
5 \cdot 3 \\
3 \cdot 0\end{array}$ & $\begin{array}{l}0 \\
0 \\
1 \cdot 5\end{array}$ & $\begin{array}{l}11 \cdot 4 \\
12 \cdot 1 \\
20 \cdot 5\end{array}$ \\
\hline L.6 & $\begin{array}{l}20 \\
40 \\
60\end{array}$ & $\begin{array}{l}0 \\
0 \cdot 7 \\
0.7\end{array}$ & $\begin{array}{l}1 \cdot 3 \\
1 \cdot 3 \\
2 \cdot 6\end{array}$ & $\begin{array}{r}6 \cdot 8 \\
9 \cdot 4 \\
11 \cdot 4\end{array}$ \\
\hline L.7 & $\begin{array}{l}20 \\
40 \\
60\end{array}$ & $\begin{array}{l}1 \cdot 3 \\
0 \\
0\end{array}$ & $\begin{array}{l}1 \cdot 3 \\
3 \cdot 2 \\
3 \cdot 8\end{array}$ & $\begin{array}{l}11 \cdot 4 \\
19 \cdot 0 \\
17 \cdot 1\end{array}$ \\
\hline L.8 & $\begin{array}{l}20 \\
40 \\
60\end{array}$ & $\begin{array}{l}0 \\
0 \cdot 6 \\
0\end{array}$ & $\begin{array}{c}0 \\
6.7 \\
10 \cdot 9\end{array}$ & $\begin{array}{r}6 \cdot 1 \\
12 \cdot 2 \\
17 \cdot 1\end{array}$ \\
\hline
\end{tabular}


The same effect was observed when DHA solution prepared from dehydroascorbic acid methanolate was used instead of the solution obtained by oxidation of ascorbic acid with bromine, a typical result being illustrated in Fig. 2.

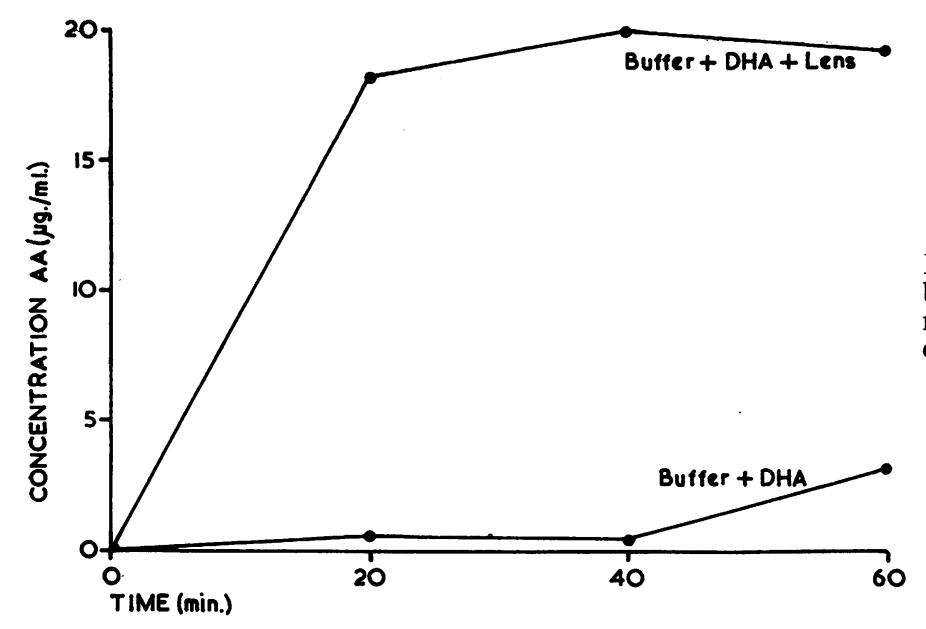

Fig. 2.-Reaction between DHA methanolate and dialysed lens extract.

During the titration of specimens from Tube I (containing lens extract and buffer) in each of the experiments recorded in Table I, no difference was observed between the colorimeter reading at $60 \mathrm{sec}$. and that at $120 \mathrm{sec}$. Therefore, none of the lens extracts contained a detectable quantity o substances which cause slow bleaching of 2:6 dichlorophenolindophenol.

The rate of formation of AA increased as the amount of lens extract added was increased, as is shown in Fig. 3 (opposite). The DHA used in this experiment was prepared from dehydroascorbic acid methanolate.

It was noticed that a faint yellow or brown colour developed occasionally in the tubes containing DHA and buffer. This colour change in solutions containing dehydroascorbic acid and ascorbic acid is well known (Kenyon and Munro, 1948; Schwartz and Leinfelder, 1955) and is probably due to the aerobic decomposition of ascorbic acid. The effect occurred in very few of the experiments and, since it was no more noticeable in the tubes containing lens extract than in those containing DHA and buffer only, no significance was attached to this observation.

(b) Reaction between Heated Lens Extract and Dehydroascorbic Acid.Lens extracts were divided into two portions, one of which was kept at room temperature, while the other was heated in a water-bath and then allowed to cool. Both were added to DHA and buffer in separate tubes and incubated in the manner described (Table II, opposite).

Preliminary heating of lens extracts to 37 or $50^{\circ} \mathrm{C}$. for $4 \mathrm{hrs} \mathrm{had} \mathrm{no} \mathrm{effect}$ on their subsequent reactions with DHA. However, extracts which had been heated to $60^{\circ} \mathrm{C}$. for $4 \mathrm{hrs}$ or to $100^{\circ} \mathrm{C}$. for $5 \mathrm{~min}$. showed greatly 
Fig. 3.- Reaction between DHA and dialysed lens extract.

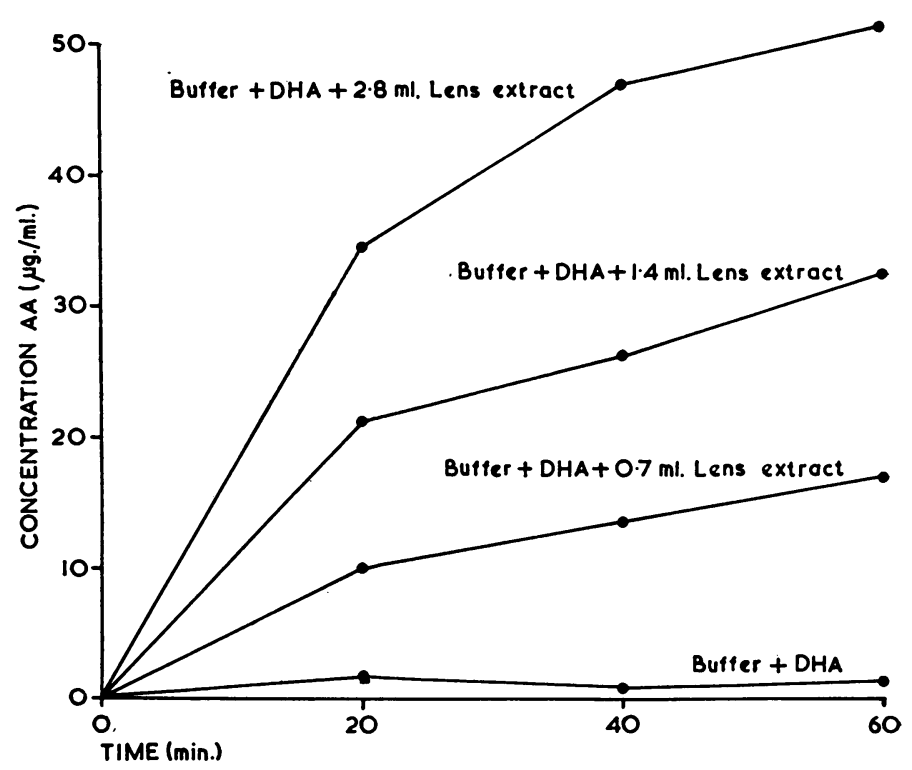

TABLE II

EFFECT OF PREVIOUS HEATING OF LENS EXTRACT ON REACTION BETWEEN DHA AND LENS EXTRACT

\begin{tabular}{|c|c|c|c|c|c|c|c|c|}
\hline \multirow{3}{*}{$\begin{array}{c}\text { Lens } \\
\text { Extract }\end{array}$} & \multirow{3}{*}{$\left|\begin{array}{c}\text { Time } \\
(\mathrm{min} .)\end{array}\right|$} & \multicolumn{5}{|c|}{ Concentration of AA $(\mu \mathrm{g} . / \mathrm{ml})}$. & \multirow{2}{*}{\multicolumn{2}{|c|}{$\begin{array}{l}\text { Preparation of } \\
\text { Heated Lens } \\
\text { Extract }\end{array}$}} \\
\hline & & \multirow[b]{2}{*}{$\begin{array}{l}0.8 \mathrm{ml} \text {. Buffer } \\
0.5 \mathrm{ml} \text {. DHA }\end{array}$} & \multirow[b]{2}{*}{$\begin{array}{l}0.8 \mathrm{ml} . \text { Buffer } \\
1.4 \mathrm{ml} \text {. Lens } \\
\text { Extract }\end{array}$} & \multirow[b]{2}{*}{$\begin{array}{l}0.8 \mathrm{ml} . \text { Buffer } \\
1.4 \mathrm{ml} \text {. Heated } \\
\text { Lens Extract }\end{array}$} & $\underset{\text { Extract }}{\text { DHA + Lens }}$ & $\begin{array}{c}\text { DHA + Heated } \\
\text { Lens Extract }\end{array}$ & & \\
\hline & & & & & $\begin{array}{l}0.8 \mathrm{ml} . \text { Buffer } \\
0.5 \mathrm{ml} \text {. DHA } \\
1.4 \mathrm{ml} \text {. Lens } \\
\text { Extract }\end{array}$ & $\begin{array}{l}0.8 \mathrm{ml} \text {. Buffer } \\
0.5 \mathrm{ml} \text {. DHA } \\
1.4 \mathrm{ml} . \text { Heated } \\
\text { Lens Extract }\end{array}$ & $\begin{array}{l}\text { Temp. } \\
\left.\text { ( }{ }^{\circ} \mathrm{C} .\right)\end{array}$ & Time \\
\hline L.9 & $\begin{array}{l}20 \\
40 \\
60\end{array}$ & $\begin{array}{l}0 \\
1 \cdot 7 \\
1 \cdot 7\end{array}$ & $\begin{array}{l}3 \cdot 5 \\
2 \cdot 9 \\
2 \cdot 3\end{array}$ & $\begin{array}{l}1 \cdot 2 \\
3 \cdot 5 \\
1 \cdot 2\end{array}$ & $\begin{array}{r}5 \cdot 8 \\
9 \cdot 2 \\
10 \cdot 9\end{array}$ & $\begin{array}{r}5 \cdot 8 \\
9 \cdot 2 \\
12 \cdot 1\end{array}$ & 37 & $4 \mathrm{hrs}$ \\
\hline L. 10 & $\begin{array}{l}20 \\
40 \\
60\end{array}$ & $\begin{array}{l}0 \\
0 \\
1 \cdot 8\end{array}$ & $\begin{array}{l}0 \\
2 \cdot 9 \\
2 \cdot 9\end{array}$ & $\begin{array}{l}0 \\
0 \\
0\end{array}$ & $\begin{array}{l}3 \cdot 5 \\
5 \cdot 8 \\
9 \cdot 3\end{array}$ & $\begin{array}{l}1 \cdot 2 \\
5 \cdot 2 \\
5 \cdot 8\end{array}$ & 50 & $4 \mathrm{hrs}$ \\
\hline L.11 & $\begin{array}{l}20 \\
40 \\
60\end{array}$ & $\begin{array}{l}2 \cdot 4 \\
3 \cdot 7 \\
4 \cdot 9\end{array}$ & $\begin{array}{l}0 \\
0 \\
0 \cdot 6\end{array}$ & $\begin{array}{l}3 \cdot 1 \\
0 \\
4 \cdot 9\end{array}$ & $\begin{array}{l}11 \cdot 6 \\
17 \cdot 7 \\
19 \cdot 5\end{array}$ & $\begin{array}{l}20 \cdot 2 \\
30 \cdot 0 \\
41 \cdot 0\end{array}$ & 60 & 4 hrs \\
\hline L.12 & $\begin{array}{l}20 \\
40 \\
60\end{array}$ & $\begin{array}{l}0 \\
1 \cdot 8 \\
1 \cdot 2\end{array}$ & $\begin{array}{l}1 \cdot 8 \\
0 \\
4 \cdot 1\end{array}$ & $\begin{array}{l}6 \cdot 5 \\
0 \\
0\end{array}$ & $\begin{array}{l}12 \cdot 4 \\
17 \cdot 7 \\
16 \cdot 0\end{array}$ & $\begin{array}{l}67 \cdot 4 \\
76 \cdot 1 \\
76 \cdot 8\end{array}$ & 100 & $5 \mathrm{~min}$. \\
\hline
\end{tabular}

enhanced activity when incubated with DHA, both the rate of formation of AA and the total amount of AA produced being increased.

(c) Reaction between Reduced Glutathione and Dehydroascorbic Acid.A solution of glutathione $(2 \mathrm{mg} . / \mathrm{ml}$.) was incubated with DHA under the same conditions as for the reaction between lens extract and DHA. The effect of preliminary heating of the GSH solution was also studied in order 
to make a comparison with the corresponding experiments with lens extract. The results appear in Table III and three points need special mention:

(i) The rate of formation of AA with this GSH solution is approximately equal to the rate found with many of the lens extracts.

(ii) Preliminary heating of the GSH solution did not increase the rate of its reaction with DHA.

(iii) When the specimens from the tubes containing GSH and DHA were titrated, there was a definite decrease in optical density between the $60 \mathrm{sec}$. and $120 \mathrm{sec}$. readings, whereas there was no fading during titration of the reaction mixtures in the experiments with lens extracts.

TABLE III

EFFECT OF PREVIOUS HEATING OF SOLUTIONS OF GLUTATHIONE ON REACTION BETWEEN GSH AND DHA

\begin{tabular}{|c|c|c|c|}
\hline \multirow{2}{*}{$\begin{array}{c}\text { Time } \\
\text { (min.) }\end{array}$} & \multicolumn{3}{|c|}{ Concentration of AA $(\mu \mathrm{g} / \mathrm{ml}$.) } \\
\hline & $\begin{array}{l}\text { Unheated GSH } \\
\text { Solution }\end{array}$ & $\begin{array}{l}\text { GSH Solution kept at } \\
60^{\circ} \text { C. for } 4 \mathrm{hrs} \\
\text { before Use }\end{array}$ & $\begin{array}{l}\text { GSH Solution kept at } \\
100^{\circ} \text { C. for } 5 \mathrm{~min} . \\
\text { before Use }\end{array}$ \\
\hline 20 & $9 \cdot 6$ & $11 \cdot 6$ & $12 \cdot 8$ \\
\hline 40 & $15 \cdot 4$ & $14 \cdot 8$ & $16 \cdot 0$ \\
\hline 60 & $17 \cdot 3$ & $15 \cdot 4$ & $14 \cdot 8$ \\
\hline
\end{tabular}

\section{Discussion}

The experiments described above demonstrate that dialysed lens extracts react with dehydroascorbic acid at $37^{\circ} \mathrm{C}$. and $p \mathrm{H} 7$ to yield one or more substances which decolorize 2:6-dichlorophenolindophenol. It is necessary to consider how much of the product, referred to as AA, can be assumed to be ascorbic acid. It is known that certain substances, such as glutathione, cysteine, and cystine, bleach 2:6-dichlorophenolindophenol, but these act at a slower rate than ascorbic acid. This has been studied by Meunier (1937), Bessey (1938), and Evelyn, Malloy, and Rosen (1938); the lastnamed pointed out that a correction for these interfering substances can be applied by taking successive readings during the colorimetric determination. A similar procedure was followed in this investigation and a correction was applied, and it is therefore concluded that sulphydryl compounds do not account for an important fraction of AA. However, the possibility remains that, during incubation, other substances were formed which were capable of decolorizing the dye as rapidly as ascorbic acid. Penney and Zilva (1943) studied the degradation of dehydroascorbic acid to 2:3-diketogulonic acid

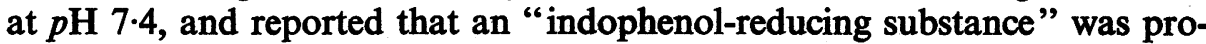
duced. The amount of this substance which was formed was comparatively small and the maximal production was not attained for $2 \mathrm{hrs;}$ it seems likely 
therefore that the product AA did not contain a high proportion of substances of this nature. It appears reasonable to conclude that most of the AA is ascorbic acid and it will be considered as such.

With regard to the mechanism of the reaction between lens extracts and DHA, one possibility is that the activity of the extracts was due to reduced glutathione which was retained in spite of dialysis; this explanation was rejected by Langham and Heald (1956) since they found that the activity of the extracts was not diminished by prolongation of the dialysis. The experiments reported above provide a further reason for rejecting the possibility of retention of reduced glutathione in the extracts. It was found that a reaction mixture, containing sufficient glutathione to form ascorbic acid from DHA at a rate comparable with that obtained with lens extracts, bleached the dye slowly during the colorimetric determination. If the activity of the lens extracts were attributable entirely to retained glutathione, then slow bleaching of the dye would be expected with the reaction mixtures containing lens extract, but in fact the colorimeter readings were steady.

The sulphydryl groups of compounds other than glutathione are capable of reducing DHA, and Szent-Györgyi (1928) demonstrated that "fixed" sulphydryl groups were active in this respect, since he observed the reduction of "oxidized hexuronic acid" by washed muscle. It is well known that lens proteins, especially $\beta$-crystallin, are rich in sulphydryl groups, and it appears possible therefore that the reduction of DHA to ascorbic acid was effected by the protein sulphydryl groups in the lens extracts.

The reaction between lens extract and DHA was potentiated if the extract had been heated previously to temperatures of $60^{\circ} \mathrm{C}$. or more, an effect contrasting with the reaction between glutathione and DHA, which, as was expected, was not enhanced by preliminary heating of the glutathione solution. It is possible that heating the lens extracts resulted in an increase in the number of sulphydryl groups, derived from lens protein, which were available for reaction with DHA and thereby increased the rate of ascorbic acid formation. An alternative explanation is suggested by the investigation by Pirie and van Heyningen (1954) of the changes in the concentrations of reduced and oxidized glutathione in extracts of lenses, prepared by extraction with water or with solutions of ethylenediaminetetraacetate (EDTA). These workers found that boiling caused regeneration of reduced glutathione in stored lens extracts prepared with EDTA. Their explanation of this finding was that oxidized glutathione cannot be separated easily from lens proteins and so dialyses rather slowly out of lens extracts, and that subsequent boiling results in its reduction by protein sulphydryl groups. Although it is possible that the increased reaction of heated lens extracts with DHA could have been due to regeneration of reduced glutathione by this mechanism, such an explanation is improbable, since aqueous extracts prepared from fresh lenses would not be expected to contain significant amounts of oxidized glutathione, according to the work of Dische and Zil 
(1950). These workers showed that the trichloracetic acid-soluble fraction of extracts of normal lenses of various species contained no significant amounts of oxidized glutathione.

It is clear that the reaction which has been demonstrated between DHA and dialysed lens extracts could account for the acceleration of ascorbic acid production from DHA and glutathione after addition of lens extract, as reported by Langham and Heald (1956). Moreover, their further observation that heated lens extracts caused greater acceleration of the reaction between DHA and glutathione than extracts which had not been heated may be explained by the finding that the reaction between DHA and lens extracts was more rapid when the extracts had been heated previously to temperatures of $60^{\circ} \mathrm{C}$. or more. These findings do not disprove the presence in lens extracts of an enzyme system catalysing the reaction between DHA and reduced glutathione, but they make evident a difficulty in the investigation of the existence of such an enzyme.

\section{Summary}

Dialysed extracts were prepared from rabbit lenses and incubated with solutions of dehydroascorbic acid at $p \mathrm{H} 7$ and $37^{\circ} \mathrm{C}$. During incubation there was a progressive increase in the capacity of the reaction mixture to decolorize 2:6-dichlorophenolindophenol. The product of the reaction was thought to be mainly ascorbic acid. The rate of formation of ascorbieg acid was increased if the lens extract had been heated previously to temperatures above $60^{\circ} \mathrm{C}$., a fact which demonstrates that the reaction is not? enzymic in nature. It is suggested that the sulphydryl groups of the lens proteins were responsible for the reduction of dehydroascorbic acid and that the number of available sulphydryl groups was increased by heating the extract. These observations do not by any means constitute proof that the ascorbic acid in the aqueous humour is lenticular in origin.

I wish to thank Dr. Maurice Langham for his advice during the preparation of this paper.

\section{REFERENCES}

Bárány, E., and Langham, M. E. (1955). Acta physiol. scand., 34, 99.

Bessey, O. A. (1938). J. biol. Chem., 126, 771.

BORSOOK, H., DAVENPORT, H. W., JeFFreys, C. E. P., and WARner, R. C. (1937). I Ibid., 117, 237.

Dische, Z., and ZiL, H. (1951). Amer. J. Ophthal., 34, May, pt. 2, p. 104.

Evelyn, K. A., Malloy, H. T., and Rosen, C. (1938). J. biol. Chem., 126, 645.

KENYON, J., and MUNRO, N. (1948). J. chem. Soc., p. 158.

KInSEY, V. E. (1950). Amer. J. Ophthal., 33, 257.

LaNGHAM, M. E., and Heald, K. (1956). Biochem. J., 63, 52.

MeUNIER, P. (1937). Bull. Soc. chim. biol. (Paris), 19, 877.

MISHIMA, K. (1952). Acta Soc. ophthal. jap., 56, 76.

Penney, J. R., and Zilva, S. S. (1943). Biochem. J., 37, 403.

PIRIE, A., and HeYNINGEN, R. van (1954). Nature (Lond.), 173, 873.

SchWARTZ, B., and LeINFELDER, P. J. (1955). Amer. J. Ophthal., 40, Nov., pt. 2, p. 224.

SZENT-GYörGYI, A. (1928). Biochem. J., 22, 1387.

Uyama, Y., and Ogino, S. (1955). Med. J. Osaka Univ., 6, 217.

U, and Mishima, K. (1955). Ibid., 6, 225. 